A I d o n a Rum ińska-Szalska

ORCID: 0000-0002-6078-8667

Szkoła Podstawowa z Oddziałami Integracyjnymi nr 105

im. Ludwiki Wawrzyńskiej w Krakowie

\title{
Dialog międzypokoleniowy jako wartość na przykładzie autorskiego projektu „Aby Senior brzmiało dumnie!”
}

\author{
Intergenerational Dialogue as a Value on the \\ Basis of the Project "Making Seniors Sound Proud!"
}

\begin{abstract}
ABSTRAKT
Wychowanie jest całożyciowym procesem, któremu podlega człowiek od momentu narodzin aż do śmierci. Proces ten opiera się na ustalonym systemie wartości, który w pierwszej kolejności przekazywany jest dziecku przez najbliższe środowisko społeczne, jakim jest rodzina. Zachodzace w Polsce i na świecie przeobrażenia społeczno-kulturowe, ekonomiczne, polityczne oraz demograficzne pozwalaja zaobserwować zmieniającq się na przestrzeni lat hierarchię wartości młodych ludzi. Szczególnie ważna jest transmisja tradycyjnych wartości egzystencjalnych, która odbywa się droga dialogu międzygeneracyjnego. Zadanie to powinno być realizowane zarówno przez rodzinę, jak i środowiska społeczne, w których funkcjonuje młody człowiek. Szczególnie ważna w tym względzie jest instyłucja szkoły. W artykule autorka prezentuje własny sposób realizacji w duchu wartości chrześcijańskich wieloetapowego i wieloaspektowego projektu o charakterze senioralnym, integrującego młodzież o różnych potrzebach edukacyjnych z osobami starszymi ze środowiska lokalnego.
\end{abstract}

SLOWA KLUCZOWE wychowanie, wartości, pokolenie, dialog międzygeneracyiny, pokoleniowa transmisja wartości

KEYWORDS

upbringing, values, generation, intergenerational dialogue, intergenerational transmission of values

SPI Vol. 23, 2020/1 ISSN 2450-5358 e-ISSN 2450-5366 DOI: 10.12775/SPI.2020.1.006 Nadesłano: 16.12.2019 Zaakceptowano: 3.04 .2020 Raporty z badań 


\section{ABSTRACT}

Upbringing is a lifelong process, one to which a person is subjected from birth to death. This process is based on an established system of values, which is first passed on to the child by the family, the immediate social environment. The ongoing socio-cultural, economic, political and demographic changes in Poland and the rest of the world indicate that the hierarchy of values of young people has changed over the years. It is essential that the generational transmission of traditional existential values is conducted through constructive intergenerational dialogue. This task should be implemented by both the family and social environment in which a young person exists. The institution of school is particularly important in this regard. In the article, the author presents her own way of implementing a multi-stage and multi-faceted senior project, integrating young people with different educational needs and the elderly from the local community in the spirit of Christian values.

„Kto wychowuje - wartościuje”.

(Wolfgang Brezinka)

\section{Wychowanie w kontekście wartości}

Wartości życiowe są nieodzownym motywatorem refleksji, zachowań i postaw człowieka. Są one kierunkowskazem i kompasem podejmowanych decyzji i wyborów. W połączeniu $z$ wewnętrzną strażnicą prawdy - sumieniem - stanowią ważny regulator życiowej aktywności człowieka, ujmowanej w sposób wieloaspektowy.

Wychowanie człowieka w kontekście aksjologicznym jest ustawicznym procesem polegającym na uznawaniu, deklarowaniu, realizowaniu oraz kreowaniu własnego świata i hierarchii wartości. Bogdan Nawroczyński, odnosząc się do aksjologicznych kwestii wychowawczych, wskazuje na dwa fundamenty życia człowieka: świata wartości (ustalonych norm) oraz możliwości i sposobu realizacji tworzonego świata (Nawroczyński 1934: 88).

Wychowanie, jako proces ukierunkowanych oddziaływań na kształtującą się w sposób holistyczny osobowość człowieka, polega na wskazywaniu wartości jako przewodników, drogowskazów godnych uznania i wyboru. Dotyczy to również ukazywania skutków 
podejmowanych decyzji, uczenia umiejętności ponoszenia konsekwencji swoich zachowań i przyjmowanych postaw w odniesieniu do siebie i innych. Celem zabiegów wychowawczych powinna być pomoc i wsparcie w decyzjach życiowych, dylematach moralnych ukierunkowujących myślenie podmiotu wychowywanego. Proces ten odbywa się poprzez tworzenie własnej koncepcji życia, systemu i hierarchii wartości, realizacji życiowych planów zgodnie $\mathrm{z}$ wewnętrznym i powszechnie akceptowanym kodeksem zasad moralnego postępowania.

Wychowanie człowieka $\mathrm{w}$ wartościach $\mathrm{i}$ do wartości to zadanie, które powinno być podejmowane przede wszystkim przez słowo i codzienny przykład dawany w rodzinie (choć nie tylko) oraz przez powołane do tego instytucje edukacyjne. $Z$ biegiem lat młody człowiek winien być wdrażany do trudnej i odpowiedzialnej sztuki samowychowania w kontekście własnego systemu wartości i wielopłaszczyznowego rozwoju.

Przeobrażenia społeczno-demograficzne i ekonomiczno-polityczne zachodzące we współczesnym świecie, pojawiające się trendy i mody kulturowe, rodzą pytania i troskę o tradycyjne wartości egzystencjalne, które modelują życie człowieka nadając mu sens i jakość. Długa lista tych wartości wyrasta $\mathrm{z}$ triady starożytnych cnót: dobra, prawdy i piękna. Można by rzec, że tym kluczowym wartościom odpowiadają wartości: moralne, intelektualne i duchowo-estetyczne. Wartości wpisują w rzeczywistość pewien sens, ukazując to, co istotne i warte pożądania. Są one filarami, na których opiera się życie społeczne, osobiste i wspólnotowe (Nowak 2000: 393). Podlegając procesowi interioryzacji, zakorzeniają się one $\mathrm{w}$ głębsze struktury duchowej sfery osobowości człowieka, co sprawia, że z biegiem lat odwoływanie się do nich w toku życiowych zdarzeń staje się w pewnym sensie odruchem emocjonalno-mentalnym. To z kolei wiąże się z doświadczaniem codzienności (uwarunkowań i sytuacji życiowych), w której funkcjonuje człowiek.

Do szczególnych wartości ogólnoludzkich, będących istotnym wyznacznikiem postępowania człowieka, należą wartości chrześcijańskie. Wartości te inspirowane są wiarą w Boga i głębią przesłania ewangelicznego. Słusznie stwierdza Marian Nowak, że chrześcijanie przyjmując „wartości ogólnoludzkie” poszukują w nich jeszcze większej głębi, pełni i integralności oraz sensu przekraczającego ten, który zdolny jest nadać im człowiek (Nowak 2000: 395-396). 
Autor dodaje, że zakładając, iż nie może istnieć wychowanie bez wartości, stwierdzamy tym samym, że nie ma wychowania tam, gdzie nie ma odwołania się do pewnego rodzaju sacrum. Wychowanie w tym kontekście powinno rozwijać i pielęgnować w człowieku „poczucie sacrum", tzn. szacunek do wartości (Nowak 2000: 393-394).

Wychowanie w kontekście wartości chrześcijańskich wynika z postrzegania świata jako stwórczego dzieła Boga, a człowieka jako istoty stworzonej na jego obraz i podobieństwo. Słusznie zauważa Michał Jóźwik, że obecnie w życiu kulturowo-społecznym ujawniają się tendencje do marginalizowania potrzeb religijnych oraz dostrzega się w cywilizacji europejskiej degradację życia duchowego ludzi. Obserwuje się dyskryminację poglądów i wartości katolickich (Jóźwik 2015: 144). Krzysztof Czykier stwierdza natomiast, że w obliczu nieustannej ekspansji mediów elektronicznych, kwestie takie jak socjalizacja i wychowanie młodych, które były dotychczas obszarami zarezerwowanymi do realizacji przez starsze pokolenia, stanowią dziś niszę, funkcjonując na wzór , tajnych fakultetów”. W dobie bycia cool, czy online nie wypada dziś człowiekowi młodemu kultywować wczorajszych wzorów, zasad, norm i wartości (Czykier 2013: 168). W tej kwestii wypowiada się także Rafał K. Wilk, który twierdzi, że obecne czasy charakteryzują się zmasowanym atakiem na wszystkie niemal przejawy postaw chrześcijańskich. W życiu codziennym z kolei zwalczane jest myślenie teistyczne, odrzucane, a nawet wyśmiewane są wszelkie przejawy religijności. Dokonuje się to często pod pozorem promocji specyficznie rozumianych „dzieł sztuki” oraz zdobyczy nauki, która jako jedna zapewnia obiektywność (Wilk 2017: 15-16).

Niebywale trudna i odpowiedzialna rola spoczywa zatem na rodzinie w zakresie krzewienia wartości (a nie pseudowartości) religijnych. Kwestia ta dotyczy codziennych intencjonalnych lub mniej niezamierzonych działań, przejawianej zgodności pomiędzy nauką a działaniem, czujnych postaw w obliczu powszechnej tendencji do podważania nauki Kościoła, nie zawsze właściwie rozumianego pojęcia wolności (a nie samowoli), walki z pokusami, lenistwem, chęcią łatwego zysku, szybkiego sukcesu, lansowania wartości materialnych. Problemy te intensyfikują się zwłaszcza w okresie adolescencji człowieka i jego współuczestnictwa $\mathrm{w}$ różnych środowiskach społecznych, które niejednokrotnie wymuszają identyfikację i uleganie nie zawsze właściwym wzorcom i ideom. 
Sztuką i wyzwaniem dla podmiotów wychowujących oraz samych wychowywanych jest utrzymanie zgodności co do traktowania i rozumienia człowieka jako istoty pozostającej w łączności z Bogiem. Wymaga to uznania godności człowieka jako osoby i jego niezaprzeczalnej wartości podmiotowo-osobowej. Człowiek jest w stanie weryfikować prawdę o sobie tylko w koegzystencji z drugim, zwłaszcza w warunkach ograniczonego komfortu i braku sprzyjających warunków życia. Być człowiekiem, nie pomimo, ale właśnie na skutek zastanych i rodzących się niedogodności, to przejaw wysokiego stopnia człowieczeństwa. To dar, którym obdarzeni są nieliczni oraz kluczowa prawidłowość relacji ogólnoludzkich, która winna być rozwijana i pielęgnowana w układzie interakcji społecznych.

\section{Istoła i sens dialogu pokoleń - transfer wartości ogólnoludzkich}

Współcześnie wokół pojęcia „pokolenie” toczy się wiele dyskusji, zarówno w tych prowadzonych w wymiarze życia codziennego, jak i z perspektywy naukowej. Termin ten ma charakter złożony i niejednoznaczny.

Samo pojęcia „pokolenie” może się odnosić do podziału na grupy, w zależności od ich określonych typów: społecznych (role społeczne i status jednostki), ekonomicznych (aktywność zawodowa) i socjalnych (prawa i obowiązki wynikające $\mathrm{z}$ wieku) oraz kalendarzowych (chronologia). Inne podejście odwołuje się do podobieństwa kulturowego, wynikającego z wpływu np. traumatycznych doświadczeń, które odcisnęly piętno w sposobie myślenia w grupie osób rozpoczynających dorosłość, wpływając na przebieg ich życia i sposób ujmowania rzeczywistości (Szukalski 2012: 12-13).

W niniejszym artykule pojęcie „pokolenie” będzie rozumiane w kontekście dialogu (relacji), zarówno w skali mikro, na linii: ojciec/matka, dziadek/babcia, pradziadek/prababcia itp.), oraz makro, w ujęciu globalnym, pozarodzinnym, w układzie dalszych relacji społecznych. Trudno jest dziś ustalić wyraźne granice wiekowe pomiędzy pokoleniami ze względu na wydłużający się okres życia człowieka. Dlatego przyjęto, że kolejne pokolenie wyznaczane jest pełnioną rolą społeczną wynikającą ze statusu: ojciec, dziadek, prapradziadek.

Prowadząc rozważania w duchu wartości chrześcijańskich w kontekście procesu wychowania młodego człowieka, należy pamiętać 
o niepodważalnej roli edukacji wartościującej pierwszego środowiska życiowego dziecka, jakim jest rodzina. To właśnie w rodzinie młody człowiek zaczyna doświadczać prawidłowości (bądź nieprawidłowości) zachodzących w jej funkcjonowaniu. To dzięki rodzinie dziecko zaczyna oceniać i wartościować zachodzące w niej procesy. To właśnie rodzina jako pierwsza realizuje bezwzględnie „podstawę programową" dzięki przekazowi uniwersalnych wartości. Obserwowanie, a następnie przejmowanie percypowanych wzorów zachowań staje się bardziej lub mniej intencjonalnym oddziaływaniem środowiska wychowawczego na dojrzewającą osobowość człowieka. Leokadia Szymczyk podkreśla, że rodzina jest zarówno nosicielem, jak i obrońcą oraz przekazicielem cenionych wartości. Poprzez styl życia, zwyczaje, nawyki, tradycję kształtuje ona osobowość dziecka, przekazując normy, wartości oraz wzory postępowania (Szymczyk 2017: 212). Z kolei Aldona Małyska zwraca uwagę, że rodzina stanowi środowisko, w którym możliwe jest spotkanie przedstawicieli wielu pokoleń. Siła tych spotkań wynika z emocjonalnego tła, żywości relacji, zaangażowania, wspólnoty ekonomicznej, bliskości gniazda. Należy również wymienić $\mathrm{w}$ tym względzie więzi pokrewieństwa i związany z nimi wspólny rodowód (Małyska 2017: 166).

$\mathrm{Na}$ definicję rodziny w aspekcie tworzonych w niej więzi wspólnotowych zwraca uwagę Andrzej Michał de Tchorzewski, podkreślając, że rodzina jest pewnym rodzajem rzeczywistości społecznej, której cechą konstytutywną jest wspólnotowy charakter życia danego zbioru podmiotów zintegrowanych w różnym stopniu więzami biologicznymi, emocjonalnymi, kulturowymi, prawnymi i gospodarczymi (Tchorzewski 2004: 56).

Transmisja wartości sprowadza się do procesu związanego $\mathrm{z}$ wewnętrznym układem małżeńskim (modyfikacja wartości małżonków na skutek wzajemnych oddziaływań) oraz ich przekazu w relacji rodzice-dzieci, który to przekaz w procesie wychowania działa na zasadzie sprzężenia zwrotnego (Rostowska 2001: 220). Wiedza o wychowaniu, jak podkreśla Władysław Cichoń, musi być oparta na wiedzy o wartościach i o człowieku (Cichoń 1980: 6). Szczególne znaczenie ma wdrażanie i otwieranie przed rozwijającym się człowiekiem świata wartości chrześcijańskich, których przekaz i wzmacnianie będzie procentowało w kolejnych etapach rozwoju człowieka. 
Według wyników badań przeprowadzonych przez Beatę Wołosiuk wśród 310 uczniów klas III szkoły podstawowej oraz ich rodziców mieszkających w powiecie bialskim, 82\% uczniów stwierdza, że to właśnie rodzice wprowadzają ich w świat wartości, 30\% wskazuje w tym względzie na nauczycieli, a 13\% typuje księdza lub katechetę. $\mathrm{Z}$ kolei $9 \%$ uważa, że sami wiedzą, jak należy postępować oraz jakich wyborów dokonywać. Warto zwrócić uwagę, że wśród listy wymienianych wartości, rodzina i wartości religijne zajmują jedne z najwyższych pozycji w hierarchii (Wołosiuk 2011: 194-201).

Interesujące analizy porównawcze w zakresie wartości cenionych przez młodzież licealną, uważaną za życzliwą ( $\mathrm{n}=143$ ) oraz niemającą takiego uznania $(n=73)$, oraz ich rodziców prowadziła Hanna Elżanowska. Analizy autorki pokazują, że zachodzi zgodność między rodzicami i dziećmi w zakresie preferowanych wartości, choć stopień tej zgodności może być różny w zależności od konkretnych wartości. Rodzice oraz młodzież różnią się poziomem zgodności w zakresie rozpatrywanych kategorii wartości, jednak są zgodni co do ich znaczenia w życiu. Badania pokazały, że w grupie osób życzliwych oboje rodzice rzadziej cenili wartości materialne oraz te związane $z$ prestiżem społecznym, z kolei ojcowie istotnie częściej cenili wartości moralne (Elżanowska 2012: 103-110).

Oprócz rodziców dziecka szczególne znaczenie w krzewieniu wartości, w tym wartości religijnych, odgrywają dziadkowie, którzy wraz ze swoimi dziećmi powinni umożliwiać żywy transfer wartości zakorzeniający się stopniowo w świadomości wnuków. Kwestia ta nabiera szczególnego znaczenia w kontekście doceniania typu rodziny wielopokoleniowej. Każde bowiem pokolenie jest nośnikiem własnych wartości, których wymiana stanowi istotny łańcuch żywego przekazu prawdy, wiary i mądrości.

Dialog pomiędzy pokoleniami - jak podkreśla Maria Braun-Gałkowska - jest cenny dla wszystkich generacji, gdyż zapewnia on ciągłość kulturową, daje poczucie bliskości i chroni przed wyobcowaniem, a jednocześnie umożliwia pomyślne pełnienie ról rodzinnych (Braun-Gałkowska 2006: 188). W tym miejscu warto przytoczyć słowa Adama A. Zycha, który generację juniorów i seniorów ukazuje w układzie niemal synergicznym i współzależnym: „Młode pokolenie jest nadzieją każdego narodu, a zarazem ważnym elementem składowym całego społeczeństwa, z kolei generacja seniorów, ludzi 
sędziwych, jest nośnikiem wielu wartości kulturowych czy społecznych" (Zych 1999: 58). Zdaniem autora, juniorzy i seniorzy są niezbędni, a nawet konieczni dla siebie. Wzajemność wymiany własnej wiedzy i umiejętności autor nazywa pięknym określeniem „darów międzypokoleniowych" (Zych 1999: 61-62).

Powyższy aspekt staje się dziś coraz bardziej istotny ze względu na wydłużający się czas trwania ostatniego etapu rozwoju człowieka. Fakt ten stanowi szansę na odnowienie tradycyjnych ogniw wartości rodzinnych i wzajemną edukację aksjologiczną. $Z$ drugiej jednak strony należy się zgodzić ze Stanisławą Steuden, że przeobrażenia społeczno-kulturowe w istotny sposób mają wpływ na kształt wspó1czesnej rodziny (Steuden 2011: 127). Szczególnie jest to widoczne $\mathrm{w}$ związku z obserwowanym niżem demograficznym, transformacją rodziny wielopokoleniowej w rodzinę nuklearną, opuszczaniem kraju przez osoby młode, często osobnym mieszkaniem seniorów ich dzieci i wnuków oraz innymi uwarunkowaniami związanymi z powszechnie lansowanymi obecnie trendami społecznego życia.

Rolę seniorów jako przewodników życia młodego pokolenia oraz strażników zbiorowej pamięci, ludzkiego i duchowego dziedzictwa akcentowali m.in. Ireneusz Celary oraz Roman Ceglarek i Mariusz Sztaba (Celary 2011; Ceglarek, Sztaba 2015). Inne badania w zakresie transmisji międzypokoleniowej podkreślają wzajemną ważność obopólnej relacji dziadków i wnuków (Dzięgielewska 1994; Łobożewicz 1994; Orzechowska 1994). Na szczególnie silny związek pomiędzy dziadkami i wnukami w kontekście żywej pedagogiki rodziny wskazują także Agnieszka Wojtanowska i Maria Braun-Gałkowska (Wojtanowska 2003; Braun-Gałkowska 2006).

Walentyna Wnuk, zwracając uwagę na potencjał przekazu kulturowego osób starszych oraz kwestie aksjologiczne w dialogu międzypokoleniowym, podkreśla, że są wartości ponadczasowe, uniwersalne i podstawowe, które ktoś musi przekazać. Pokoleniowy przekaz tych wartości jest podstawą dialogu międzypokoleniowego. Starsi ludzie są „żywymi kartami historii” rodziny, miasta, regionu (Wnuk 2013: 28). Niestety, cenne stronice tej historii powoli zamykają pewne rozdziały tragicznych wydarzeń, których świadkowie chylą się ku zachodowi życia. Dlatego ważna niezmiernie jest „sztafeta” przekazu tego, co umacnia niezawodną prawdę i tworzy historyczne oblicze narodu. 
Młodzi ludzie, którzy dziś wzrastają w świecie coraz bardziej zaawansowanych technologii komunikacyjnych, nowych trendów i metod nauczania oraz pluralistycznego świata kultury, są wartościowym ogniwem w łańcuchu międzygeneracyjnym zaspakajającym potrzeby poznawcze osób starszych. Prekursorką badań, akcentującą znaczenie i rolę więzi pokoleniowych w tym zakresie, była amerykańska uczona Margaret Mead, autorka koncepcji kultury prefiguratywnej (Mead 2000: 23). W świetle dokonujących się w świecie techniki przeobrażeń teoria autorki znalazła z perspektywy czasu swoje uzasadnienie. Wilhelm Schmid, niemiecki filozof, relacje rodzinnych pokoleń ujmuje w pięknej metaforze pomostu między „małą” historią rodzinną a „wielką" historią minionych czasów (Schmid 2017: 87). Wartości chrześcijańskie stanowią ważne spoiwo łączące światy sacrum i profanum w kontekście idei humanizmu i człowieczeństwa oraz związku człowieka z Bogiem. Należy być szczególnie czujnym w uwrażliwianiu młodego człowieka na szacunek do omawianej kategorii wartości, pomimo różnic w wierze, poglądach i przekonaniach. Wzmacnianie i dowartościowywanie dziecka za przejawy wszelkich właściwych postaw w kontekście zanikających wartości religijnych - co dokonuje się kosztem lansowania nowoczesnych trendów czy stylów - stanowi jeden ze sposobów przetrwania i trwałości tego, co nadaje pewność i stabilność w życiu.

Warto pamiętać w praktyce życia słowa Adama Zycha, który stwierdza: „Niezwykle potrzebne są kontakty i spotkania dialogu dwu pokoleń - wstępującego i odchodzącego. Wówczas poprzez szczery i autentyczny dialog generacji, a nie kontrowersję i konfrontację, łatwiej poszukać odpowiedzi na pytanie, jak być w zgodzie z samym sobą i drugim człowiekiem, a zarazem z otoczeniem społecznym" (Zych 1999: 23).

\section{Dialog pokoleń jako potrzeba i pedagogiczne wyzwanie}

Współczesny świat wychowujący młode pokolenie powinien być nastawiony na promocję „sztuki prostoty” (Loreau 2008: 17-96), minimalizującej hołdowanie wartościom materialnym, egoistycznej wygodzie, woli łatwego i bezwysiłkowego zysku oraz zbytniemu centralizowaniu własnego ja. Pedagogika ku wartościom, w tym wartościom chrześcijańskim, stanowi trudny do realizacji rozdział naczelnego 
programu wychowania nastawionego na integrację pokoleń, zwrócenie się ku historii, tradycji, patriotyzmowi i Bogu. Zdaniem Ariela Dołęgowskiego, integracja ta dotyczy łączenia jednostek, zbiorowości w różnym przedziale wiekowym, celem zapobiegania izolacji i marginalizacji społecznej w oparciu o zasoby poszczególnych grup wiekowych oraz wzmacnianie więzi i relacji międzypokoleniowych (Dołęgowski 2015: 49). Sabina Pawlas-Czyż podkreśla, że „system edukacji jest tą wyjątkową przestrzenią w życiu każdego człowieka, który tę miarę może i powinien spełniać, podnosząc jego jakość życia na wszystkich kolejnych etapach" (Pawlas-Czyż 2008: 23). Wyzwaniem i zadaniem współczesnej szkoły jest troska o zapewnienie płynności przekazu „darów międzypokoleniowych” w formie integracji juniorów z seniorami drogą nie tylko uczestnictwa w świętach i imprezach okolicznościowych, lecz także organizowanych w miarę możliwości cyklicznie spotkań, grup wzajemnego wsparcia i innych form będących płaszczyzną wzajemnego ubogacania się. Aleksander Kamiński zwraca słuszną uwagę, że społeczeństwo wychowujące powinno sprzyjać inwestycji w ludzi młodych i dorosłych na rzecz szczęśliwszego trzeciego wieku (Kamiński 1975: 10).

Można powiedzieć, że szkoła tym bardziej jest współczesna, im bardziej promuje tradycyjne wartości poprzez praktyczne, codzienne działania w procesie edukacyjno-wychowawczym. Szkoła wielopodmiotowej i wieloaspektowej nauki i pracy to szkoła otwarta na szersze horyzonty działań, mobilizacji do różnorakiej aktywności społecznej. To szkoła rozumiejąca problem jako wyzwanie, zadanie i nową szansę na wielokierunkowy rozwój. Jolanta Twardowska-Rajewska zwraca uwagę, że istnieje ogromne zapotrzebowanie związane ze strategiami wspierającymi seniorów $\mathrm{w}$ ich dążeniu do aktywnego życia oraz współdziałania z młodymi na rzecz społeczeństwa międzypokoleniowego oraz inkluzji społecznej. Starość, jak zauważa autorka, jest problemem młodych, a obecna praca na rzecz seniorów to praca dla wszystkich obecnych pokoleń. „Ars senescendi” (sztuka starzenia) jest więc wyzwaniem dla całego społeczeństwa. Wymaga to edukacji do zdrowego stylu życia na rzecz starości i długowieczności „od juniora do seniora” w szkole, Kościele, społeczności lokalnej, $\mathrm{w}$ rodzinie wielopokoleniowej $\mathrm{w}$ zakresie promocji zdrowia i profilaktyki prozdrowotnej (Twardowska-Rajewska 2013: 183). 
Należy zwrócić także uwagę na cele kształcenia oraz warunki i sposób realizacji ujęty w przedmiocie wychowania do życia w rodzinie (niestety o statusie przedmiotu nieobowiązkowego), realizowanego od klasy V szkoły podstawowej, między innymi poprzez: „ukazywanie wartości rodziny w życiu osobistym człowieka, wnoszenie pozytywnego wkładu w życie swojej rodziny, [...] wybór i urzeczywistnianie wartości służących osobowemu rozwojowi, [...] wspieranie rozwoju moralnego i kształtowania hierarchii wartości” (Rozporządzenie Ministra Edukacji Narodowej... 2017: 197-201).

Dialog młodości ze starością łączy ze sobą jeszcze jedno pośrednie ogniwo, mianowicie najdłuższy proces $\mathrm{w}$ fazie rozwoju ontogenetycznego, jakim jest starzenie się, trwający już od samych narodzin człowieka. Aspekt, o którym jest mowa, wpisuje się w postulat Kamińskiego, który traktuje pedagogikę jako naukę o „wychowaniu osób wszelkich generacji wieku" poprzez wspieranie pomyślnego rozwoju psychofizycznego, społecznego i kulturalnego (Kamiński 1975: 7). Ten budujący dialog myśli i czynu tworzy nową jakość relacji, przeżyć, a także wzmacnia poczucie dobrostanu życiowego.

\section{„Aby Senior brzmiało dumnie!” - autorski projekt w dialogu myśli i czynu}

Mając na uwadze istotne znaczenie podtrzymywania i kreowania świata wartości drogą integracji i solidarności pokoleń, autorka artykułu podjęła wielofazowe, prosenioralne działania projektowe, integrujące osoby starsze oraz niepełnosprawne z uczniami zdrowymi i ze specjalnymi potrzebami edukacyjnymi i zdrowotnymi. Miejscem realizacji działań był Zespół Szkół Ogólnokształcących Integracyjnych nr 5 w Krakowie na Osiedlu Słonecznym $12^{1}$. Szkoła ta umacnia więzi i tradycje kulturowe, akcentując w swych działaniach wartości rodziny zarówno nuklearnej, jak i wielopokoleniowej, sprzyjając systematycznej i trwalej inkluzji wielopodmiotowej w działaniach na rzecz edukacji i wychowania.

1 Nazwa placówki obowiązywała do roku szkolnego 2017/18. Zmiana nazwy na: Szkoła Podstawową z Oddziałami Integracyjnymi nr 105 im. Ludwiki Wawrzyńskiej nastąpiła zgodnie z Ustawą o Prawie oświatowym z dn. 14 XII 2016 r., poz. 59. rozdz. 1, art. 18. 
Ogólnym zamierzeniem podjętych działań było promowanie i rozwijanie wśród uczniów najistotniejszych, ogólnoludzkich wartości i postaw społecznych: tolerancji, wrażliwości, szacunku, integracji, wzajemnej pomocy, przedsiębiorczości oraz budowania poczucia sensu i jakości życia osób młodszych i starszych poprzez integrację i twórczą współpracę. Istotny był fakt wpajania przekonania wśród uczestników projektu, że „metryka” nie jest wyznacznikiem granicy społecznej aktywności człowieka, a przybywające lata dają szansę na dalszy rozwój. Specyfika projektu dotyczyła jego wieloaspektowości, wielokierunkowości i wielopodmiotowości, które zostały omówione $\mathrm{w}$ artykule.

\section{Hastowe cele projektu}

- „Włączanie na pierwszym planie!” - stwarzanie możliwości do wspólnych, wielopodmiotowych działań: uczniów, osób starszych, instytucji rządowych i pozarządowych w ramach wzajemnej współpracy, zgodnie z założeniami pedagogiki inkluzyjnej.

- „Integrowanie to ważne zadanie” - zacieśnianie więzi międzypokoleniowych (w tym rodzinnych) młodzieży w różnym wieku i o zróżnicowanych potrzebach edukacyjnych i zdrowotnych z osobami starszymi oraz kultywowanie pierwowzoru rodziny wielopokoleniowej wpływającej na kształtowanie osobowości młodego pokolenia.

- „Horyzontów otwieranie, ustawiczne nauczanie” - podejmowanie działań o charakterze interdyscyplinarnym (kulturalno-rozrywkowych, edukacyjnych, rekreacyjno-sportowych, tanecznych, naukowo-warsztatowych, sportowych itp.).

- „Rozwój zrównoważony jakością mierzony” - praktyczne uświadamianie celowości wspólnego, twórczego, refleksyjnego realizowania się, promowania zdrowego (w ujęciu holistycznym) stylu życia w zależności od własnych potrzeb, woli i możliwości. Budowanie wśród osób starszych nowej jakości życia, wewnętrznej integralności, podmiotowości i społecznej tożsamości. $Z$ punktu widzenia osób starszych rozwój ten jest pozametrykalną okazją spełniania się i spędzania w towarzystwie osób młodszych czasu wolnego. $Z$ punktu widzenia juniorów jest praktycznie realizowaną drogą ku dojrzewaniu i dorosłości. 
- „Każde pokolenie ma własny głos” - rozwijanie umiejętności konstruktywnego i życzliwego dialogu (słowa i czynu) jako mostu między pokoleniami poprzez wspólne spędzanie czasu w różnorodnych formach aktywności.

Realizacji powyższych celów sprzyjała wielopodmiotowa współpraca z nauczycielami, absolwentami szkoły, Klubami i Centrami Seniora, PTTK, instytucjami kulturalno-oświatowymi (domami kultury, muzeami, kinami działającymi na rzecz rozwoju seniorów), szkołami ze środowiska lokalnego (promocja usług kulinarno-cukierniczych, prowadzenie warsztatów carvingu), Radą Dzielnicy XVIII, władzami miasta Krakowa ds. polityki senioralnej, parafią Matki Boskiej Częstochowskiej w Krakowie.

Znaczenie pojęcia czasu wolnego przyjęto za Marią Czerepaniak-Walczak, która do jego określenia posługuje się kategoriami podmiotowymi. Podejście to charakteryzuje współwystępowanie wszystkich cech omawianego pojęcia: dobrowolność treści i form zachowań, brak komercyjności i poczucie satysfakcji (Czerepaniak-Walczak 2009: 223). Założenia realizowanego projektu wpisywały się w aksjologiczno-etyczne refleksje inspirowane humanizmem i personalizmem. Dzięki zachowaniu regularności spotkań (a nie tylko ich okolicznościowego charakteru) miały one wymiar cykliczny.

Formami realizacji działań były m.in.: spotkania integracyjno-towarzyskie, wieczornice okolicznościowe (świąteczne), spotkania językowe (np. „W niemieckim tyglu rzeczywistości”), sportowo-rehabilitacyjne, taneczne, twórcze, rekreacyjne, np. tematyczna wycieczka do Lanckorony połączona $\mathrm{z}$ formą marszu nordic walking oraz udziałem w „IX Rajdzie Konfederatów Barskich”. Spotkania towarzyskie obejmowały m.in. część kawiarniano-poetycką, połączoną z promocją twórczości uczniów i seniorów; kulturalną-rozrywkową powiązaną z układami choreograficznymi uczniów, quizami, formami integracyjnymi i teatralnymi; konsumpcyjną - poczęstunek często powiązany $z$ tradycją świąteczną lub tematycznym przesłaniem spotkania. W ramach współpracy seniorzy uczestniczyli w kręceniu edukacyjnych filmów lub spotów, które zdobywały nagrody i wyróżnienia.

Konferencja zorganizowana w ZSOI nr 5 w Krakowie z inicjatywy dyrekcji szkoły oraz autorki projektu „Integracja pokoleniowa szansą ustawicznego rozwoju" podsumowywała dotychczasowe działania. Otwierała ona tym samym kolejny cykl działań zatytułowany 
„Wartości i Pokolenia, czyli Katharsis Katechezo”, będący odpowiedzią na sformułowane postulaty m.in. podczas pracy warsztatowej na konferencji ogólnoszkolnej. Celem tej edycji działań był wspólny rozwój dzięki krzewieniu wartości religijnych wśród społeczności lokalnej seniorów i juniorów w warunkach parafialnych, przy współpracy różnych podmiotów z kręgu kultury, nauki, sztuki oraz religii (Referat Misyjny Prowincji Polski Południowej Towarzystwa Jezusowego w Krakowie). Spotkania miały miejsce 1-2 razy w miesiącu po mszy świętej w auli parafii Matki Boskiej Częstochowskiej w Krakowie. Tematyka spotkań była prowadzona z uwzględnieniem wyników przeprowadzonej wśród seniorów ankiety diagnozującej ich zainteresowania. Analiza ankiety wskazała na największe zainteresowanie tematyką sensu życia, wartościami, zdrowym stylem życia, historią, sylwetkami świętych znanych i nieznanych. W realizowanym przedsięwzięciu uczestniczyli uczniowie reprezentujący wszystkie etapy edukacyjne. W zorganizowanym cyklu aktywnych rekolekcji wielkopostnych pod hasłem „Prawda, Dobro, Piękno” uczestniczyło około 430 uczniów z macierzystej szkoły oraz aż ponad 1000 (!) uczniów ze szkół znajdujących się poza Krakowem. Formami realizacji spotkań były: aktywność teatralno-filmowa seniorów i juniorów, twórczość inspirowana biografią m.in. bł. Jana Beyzyma, bł. Chiary Luce Badano, św. Dominika Savio, św. Tereski od Dzieciątka Jezus, msze święte z aktywnym udziałem uczestników, integracja pokoleń, inscenizacje patriotyczne, gala pokoleń „Twórczo, zdrowo i kolorowo!”2 Przygotowano prezentacje dotyczące zbilansowanych diet, ogólnoświatowego problemu marnowania żywności. Przeprowadzono warsztaty biżuterii ekologicznej, carvingu, różnych rodzajów kuchni (kuchnia Jezusa, staropolska i współczesna). Stoiska eksperckie prezentowały i omawiały m.in. zagadnienia związane ze związkiem między grupą krwi a prawidłowym odżywianiem, doradztwem zakupowym, Loterią Zdrowia. Z kolei biesiada pod hasłem „Pasje juniorów i seniorów”3 sprzyjała wspólnemu dzieleniu się własną twórczością i zainteresowaniami. Każdej edycji projektu przyświecal „przekaz dobra”, czyli dzielenie się upominkami i żywnością z osobami chorymi i niepełnosprawnymi.

2 Inicjatywa ta zdobyła ogólnopolską nagrodę II stopnia (2017) przyznawaną przez Nestlé Polska „Winiary”.

3 Przedsięwzięcie zostało nagrodzone certyfikatem „Szkoła łącząca pokolenia 2018”. 


\section{Efekty projektu}

Projekt miał charakter uznaniowy, jego poszczególne etapy były oceniane w wojewódzkich i ogólnopolskich konkursach. I etap projektu „Cała naprzód!” zajął I miejsce w Ogólnopolskim Konkursie „Ambasador Miejsc” (organizator „Szkoła Pod Żaglami” kapitana Krzysztofa Baranowskiego). Za otrzymany grant zorganizowano dla grupy emerytów i uczniów zaplanowaną w zadaniu konkursowym trzydniową wycieczkę „Szlakiem zamków małopolskich wiecznie żywej historii” wraz z atrakcjami i noclegiem na Zamku w Niedzicy. Program obejmował zwiedzanie miast i ich zabytków od Dobczyc poprzez Wytrzyszczkę, Niedzicę, Nowy Sącz, aż do Nowego Wiśnicza i Koryznówkę. Rozszerzony w obszarach działań II etap "Juniorzy - Seniorom” zdobył tytuł Małopolskiej Szkoły z Pasją (2015) oraz został wyróżniony w ogólnopolskim konkursie „Projekt z klasą". Działania senioralne zostały również ujęte w wyróżnionym projekcie konkursowym „Każdy jest komuś potrzebny” organizowanym przez fundację Anny Dymnej „Mimo wszystko”.

Podjęte aktywności projektowe wielozakresowo integrowały ich adresatów. Sprzyjały aktywnemu stylowi życia, wzajemnej edukacji i samopoznaniu. Kontakt z człowiekiem stawał się żywą lekcją historii, doświadczenia, refleksji i spotkania "starszego z młodszym”. Uczestnicy w sposób rozwojowy i użyteczny społecznie spożytkowywali swój czas wolny. Spotkania stały się okazją do realizacji wartości ogólnoludzkich i humanistycznych. Uczniowie mieli okazję do zaistnienia, samorealizacji, odnoszenia indywidualnych i grupowych sukcesów. Tym samym wzrastało u nich poczucie własnej wartości i jakości pracy w zależności od potrzeb, możliwości i zainteresowań. Podjęte działania przekładały się na wzrost liczby pozytywnych ocen z zachowania oraz przedmiotów nauczania w zależności od podejmowanych aktywności. Miały one charakter terapeutyczno-edukacyjno-wychowawczy. Wewnętrzny rozwój, otwartość, zwłaszcza uczniów o specjalnych potrzebach, praca nad emocjami - wszystko to miało duże znaczenie dla rozwoju osobowościowego uczestników programów, co w przyszłości może zaowocować dalszym rozwojem ich postaw prospołecznych. Żywa nauka bezinteresowności, szacunku i opieki kształtowała najbardziej pożądane postawy ogólnoludzkie w imię wartości humanistycznych. Realizacja projektu przyczyniła 
się do minimalizowania poczucia pasywności osób starszych, wzmacniała też odczucie bycia potrzebnym i ważnym. Prace twórcze seniorów (albumy wspomnien, poezja, pamiętniki itp.) stanowiły istotną pomoc dydaktyczną dla uczniów podczas lekcji. Działania te przyczyniły się dodatkowo do kreowania pozytywnego wizerunku szkoły w środowisku oraz do jej promocji poprzez fotorelację działań w prasie lokalnej, wielopodmiotową wspólpracę, upowszechnianie polityki i systemu działań wobec osób starszych.

\section{Zakończenie i wnioski}

Podjęte działania były zgodne $\mathrm{z}$ fundamentalnymi zasadami nauczania określonymi w rozważaniach Jacques'a Delorsa, przewodniczącego Międzynarodowej Komisji UNESCO do spraw Edukacji dla XXI wieku w aspekcie permanentnej edukacji. Koncepcja oparta jest na czterech filarach: „Uczyć się, aby wiedzieć; uczyć się, aby działać; uczyć się, aby żyć wspólnie; uczyć się, aby być” (Delors 1998: 85). Realizacja projektu spotkała się z dużym poparciem ze strony rodzin uczniów, osób starszych, chorych, niepełnosprawnych, podmiotów współpracujących. Działania mają charakter ciągły i są odpowiedzią na zgłaszane potrzeby uczniów, seniorów oraz na apele sygnalizowane przez naukowców. Wypełniają one pewną edukacyjno-wychowawczą niszę w zakresie działań na rzecz integracji i solidarności międzypokoleniowej. Wyzwalają realizacyjny styl egzystencji człowieka, kształtując tym samym poczucie jakości i sensu jego życia.

$\mathrm{Na}$ koniec można wyprowadzić wnioski aplikacyjne wynikające z omówionych powyżej działań. Mogą z nich skorzystać placówki oświatowe i instytucje wspierające rozwój seniorów i juniorów:

- zalecane jest wdrażanie dzieci i młodzieży do twórczego zagospodarowania czasu wolnego wraz z osobami starszymi w sposób zgodny $\mathrm{z}$ ich potrzebami, zainteresowaniami i możliwościami;

- należy opracowywać interesujące oferty zajęć integracyjnych uwzględniających potencjał osób starszych wraz z propozycją wyakcentowania ich roli jako podmiotów wspierających $\mathrm{w}$ procesie edukacji i opieki; 
- wskazane jest realizowanie zaplanowanych działań w zespołach wychowawców, opiekunów przy wsparciu podmiotów ze środowiska lokalnego;

- należy traktować wszystkich beneficjentów działań jako równoprawnych i ważnych kreatorów współtworzonej rzeczywistości w imię pedagogiki wartości i konstruktywnego dialogu. Zasadne byłoby także przemyślenie nadania przedmiotowi wychowania do życia w rodzinie rangi przedmiotu obowiązkowego, w którym szczególne miejsce można byłoby poświęcić pedagogice prosenioralnej.

Kolektywne podjęcie integracyjnej współpracy juniorów i seniorów jest ukłonem w stronę historii, tradycji, a przede wszystkim człowieka. Pamiętajmy, że dając innym „wiosnę” w „jesieni ich życia”, budujemy wspólne „przedwiośnie”.

\section{Bibliografia}

Braun-Gałkowska M.(2006).Nowe role spoteczne ludzi starych, [w:] S. Steuden, M. Marczuk (red.), Starzenie się a satysfakcja z życia, Lublin: Wydawnictwo KUL, s. 122-195.

Ceglarek R., Sztaba M. (2015). Pozytywne aspekty starości. Refleksja w świetle personalizmu o inspiracji chrześcijańskiej, [w:] K. Jagielska, A. Mirczak (red.), Starzejemy się w dobrym stylu, Kraków - Świętochłowice: Wydawnictwo Scriptum, s. 107-134.

Celary I. (2011). Aktywność seniorów w spoteczno-religijnym wychowaniu dorastajacych wnuków, [w:] A. Fabiś, M. Muszyński (red.), Spoteczne wymiary starzenia się, t. 4, Bielsko-Biała: Stowarzyszenie Gerontologów Społecznych; Wyższa Szkoła Administracji, s. 49-58.

Cichoń W. (1980). Aksjologiczne podstawy teorii wychowania, Kraków: Uniwersytet Jagielloński.

Czerepaniak-Walczak M. (2009). Od próżniaczenia do zniewolenia - w poszukiwaniu dyskursu czasu wolnego, [w:] E. Marynowicz-Hetka (red.), Pedagogika spoteczna. Podręcznik akademicki, t. 2, Warszawa: Wydawnictwo Naukowe PWN, s. 219-235.

Czykier K. (2013). Międzygeneracyjna transmisja kultury w rodzinie wiejskiej wielopokoleniowej. Problem cyfrowego wykluczenia $i$ dystansu międzypokoleniowego, „Acta Universitatis Lodziensis. Folia Oeconomica”, t. 297, s. $159-170$.

Delors J. (1998). Edukacja - jest w niej ukryty skarb, przeł. W. Rabczuk, Warszawa: Stowarzyszenie Oświatowców Polskich; Wydawnictwa UNESCO. 
Dołęgowski A. (2015). Między nami nie ma granic - o integracji międzypokoleniowej, [w:] A. Leszczyńska-Rejchert, L. Domańska, E. Subocz (red.), Seniorzy w pryzmacie koncepcji "Spoteczeństwo dla wszystkich grup wieku”, Olsztyn: Wydawnictwo UWM, s. 45-55.

Dzięgielewska M. (1994). Dziadkowie w opinii studentów, „Zeszyty Problemowe PTG”, t. 2, nr 4, s. 138-142.

Elżanowska H. (2012). Międzypokoleniowa transmisja wartości w rodzinie, [w:] O. Gorbaniuk, B. Kostrubiec-Wojtachnio, D. Musiał, M. Wiechetek (red.), Studia z Psychologii w KUL, t. 18, Lublin: Wydawnictwo KUL, s. 97-114.

Jóźwik M. (2015). Międzypokoleniowy przekaz wartości w rodzinie, „Wrocławski Przegląd Teologiczny”, t. 23, nr 1, s. 139-154.

Kamiński A. (1975). Pedagogika w stużbie gerontologii spotecznej, „Człowiek w Pracy i Osiedlu", nr 4, s. 7-26.

Loreau D. (2008). Sztuka prostoty, przeł. J. Sobotnik, Warszawa: Jacek Santorski \& Co Agencja Wydawnicza.

Łobożewicz T. (1994). Rekreacja i turystyka dziadków z wnukami, „Zeszyty Problemowe PTG”, t. 2, nr 4, s. 163-167.

Małyska A. (2017). Seniorzy nauczycielami patriotyzmu, „Studia Socialia Cracoviensia" 9, nr 2(17), s. 163-180.

Mead M. (2000). Kultura i tożsamośc. Studium dystansu międzypokoleniowego, przeł. J. Hołówka, Warszawa: Wydawnictwo Naukowe PWN.

Nawroczyński B. (1934). Świat faktów i swiat wartości jako czynniki wychowania moralnego, [w:] Komitet Organizacyjny VI-go Międzynarodowego Kongresu Wychowania Moralnego, Sity moralne wspólne wszystkim ludziom, ich zródta i rozwój przez wychowanie. Referaty wygłoszone na IV Międzynarodowym Kongresie Wychowania Moralnego w Krakowie, Bydgoszcz: Zakłady Graficzne „Biblioteka Polska w Bydgoszczy”, s. 88-93.

Nowak M. (2000). Podstawy pedagogiki otwartej. Ujęcie dynamiczne w inspiracji chrześcijańskiej, Lublin: Redakcja Wydawnictwo KUL.

Orzechowska G. (1994). Miejsce i rola cztowieka starszego w rodzinie wiejskiej, „Zeszyty Problemowe PTG”, t. 2, nr 4, s. 110-118.

Pawlas-Czyż S. (2008). Przeciw ageizmowi. O potrzebie wzmacniania spotecznej pozycji cztowieka starego, „Wychowanie na co Dzień”, nr 7-8, s. 32-36.

Rostowska T. (2001). System wartości rodziców i dzieci jako zadanie rozwojowe, [w:] D. Kornas-Biela (red.), Rodzina. Źródto życia i szkota mitości, Lublin: Towarzystwo Naukowe KUL, s. 217-229.

Rozporządzenie Ministra Edukacji Narodowej z dn. 24 II 2017 r., poz. 356, w sprawie podstawy programowej wychowania przedszkolnego oraz podstawy programowej kształcenia ogólnego dla szkoły podstawowej, w tym dla uczniów z niepełnosprawnością intelektualną w stopniu umiarkowanym lub znacznym, kształcenia ogólnego dla branżowej 
szkoły I stopnia, kształcenia ogólnego dla szkoły specjalnej przysposabiającej do pracy oraz kształcenia ogólnego dla szkoły policealnej (Dz.U. 2017, poz. 356).

Schmid W. (2017). Spokój ducha. Co zyskujemy z wiekiem, przeł. B. Niedźwiedzka, Warszawa: Grupa Wydawnicza Foksal.

Steuden S. (2011). Psychologia starzenia się i starości, Warszawa: Wydawnictwo Naukowe PWN.

Szukalski P. (2012). Solidarność pokoleń. Dylematy relacji międzypokoleniowych, Łódź: Wydawnictwo UŁ.

Szymczyk L. (2017). Rola rodziny w rozwijaniu systemu wartości, „Łódzkie Studia Teologiczne", t. 26, nr 1, s. 7-20.

Tchorzewski A.M. de (2004). Obszary refleksji i badań pedagogicznych nad rodzina, [w:] A.W. Janke (red.), Pedagogika rodziny na progu XXI w., Toruń: Wydawnictwo Edukacyjne Akapit, s. 50-59.

Twardowska-Rajewska J. (2013). Deficyty opiekuñcze wobec osoby starszej, [w:] A. Kotlarska-Michalska (red.), Cztowiek stary w rodzinie i spoteczeństwie, t. 23, Poznań: Wydawnictwo Naukowe UAM, s. 171-185.

Wilk R.K. (2017). O sensie życia. Fundamentalny dramat cztowieka, Kraków: Inicjatywa Ewangelizacyjna Wejdźmy na Szczyt.

Wojtanowska A. (2003). Wychowawczy przekaz wartości w rodzinie wielopokoleniowej, [w:] J. Homplewicz (red.), Pedagogika jesieni. Problemy wychowawcze ludzi starszych, Rzeszów: Wydawnictwo: Instytut Teologiczno-Pastoralny im. św. Józefa Sebastiana Pelczara, s. 119-145.

Wołosiuk B. (2011). Wartości chrześcijañskie w wychowaniu dzieci w mtodszym wieku szkolnym, „Paedagogia Christiana”, nr 1(27), s. 185-202.

Wnuk W. (2013). Potencjat osób starszych, [w:] P. Błędowski, A. Stogowski, K. Wieczorkowska-Tobis (red.), Wyzwania wspótczesnej gerontologii, Poznań: Wydawnictwo Naukowe Wyższej Szkoły Nauk Humanistycznych i Dziennikarstwa, s. 21-32.

Zych A. (1999). Cztowiek wobec starości. Szkice z gerontologii spotecznej, Katowice: Wydawnictwo „Sląsk”.

\title{
ADRES DO KORESPONDENCJI
}

\author{
Mgr Aldona Rumińska-Szalska
}

Szkoła Podstawowa z Oddziałami Integracyjnymi nr 105

im. Ludwiki Wawrzyńskiej w Krakowie

e-mail: alszal@op.pl 